\title{
Marketing Efficiency In The Distributive Trade Channel For Onions In Osun State
}

Doi: $10.29023 /$ alanyaakademik.351608

\author{
Adegbite ADEDEJI, Adejobi Adedeji OLUSAYO \\ Department of Agricultural Economics, Obafemi Awolowo University, Ile-Ife, P.M.B 13. \\ Nigeria Correspondence: adedejiadegbite@gmail.com.+2347068464568
}

\begin{tabular}{ll} 
& ABSTRACT \\
\cline { 2 - 3 } Keywords: & $\begin{array}{l}\text { The perishable nature of vegetables demands an effective and reliable } \\
\text { chain/channel of distribution for fast disposal. Performance of the existing }\end{array}$ \\
Channel & distributive channels, marketing efficiencies of the channel operators and \\
Distributive & factors that influenced the marketing efficiencies of the marketing operators \\
Efficiency & are integral to effective marketing. Much attention has not been given to this \\
Marketing & in the agricultural marketing literature in Nigeria. Marketing efficiency \\
Operators & analysis revealed that marketing of onions by bulk merchants, wholesalers \\
Received:13.11.2017 & and retailers is most efficient in one of the selected markets at $149 \%, 343 \%$ \\
Accepted:27.02.2018 & and 275\% respectively. Transaction loss, sales volume, transportation cost, \\
wages, association dues, stall rent and cost of capital are factors that affect & onion marketers in the study area.
\end{tabular}

\section{INTRODUCTION}

Onion is the second most important vegetable in Nigeria after tomato and pepper (Hussaini, Amans and Ramalan, 2000). However, the perishable nature of onions demands comprehensive planning for movement, storage, processing and distribution. The growth of vegetable industry as a commercial proposition largely depends mainly on allied enterprises like storage, processing, marketing, maintenance and service enterprises to encourage vegetable enterprise (Agricultural information, 2011). Recent trends have shown that marketing agricultural output is becoming an increasingly difficult occupation for marketers (Ayinde, 2005).

Agricultural Technology (Agrictech) Portal (2008) observed that farmers producing agricultural produce are scattered in remote villages while consumers are in semi-urban and urban areas. Produce has to reach consumers for its final use and consumption. There are different agencies through which produce passes and reaches the consumer also known as market channel or channel of distribution. The market channel or channel of distribution therefore is a path traced in the direct or indirect transfer of title of a product as it moves from a producer to an ultimate consumer or industrial user. Thus, channel of distribution of a product is the route taken by the good as it moves from the producer to the consumer or industrial user (Agrictech Portal, 2008).

Marketing channel (distribution channel) is a set of various agencies (market intermediaries) arranged in a particular way to accomplish the movement of a product from the producer to the final consumers (Adejobi and Adeyemo, 2012). In addition, marketing channel is interdependent organizations that help make a product available for use or consumption by the consumer or business users. Channel intermediaries are firms or individuals such as 
wholesalers, agents, brokers or retailers who help move a product from the producer to the consumer or business user (Adejobi and Adeyemo, 2012).

Production is incomplete until goods/commodities produced reach the final consumers. The movement of product from producer to consumer is an important function of marketing. It is the obligation of the producer to make goods available at the right place, the right time, the right price and in the right quantities. The process of making goods available to the consumer needs effective channel of distribution (Adejobi and Adeyemo, 2012).

Moreover, it is observed that a sizable number of producers operate on a very small scale that could be considered economically non-viable. Farmer (producer's) inability to analyze effectively the cost-benefits associated with production and marketing/distribution activities or lack of supply chain structures further worsens the situation (Adejobi 2005). In other words, food distribution/marketing by farmers and their families, mostly in the immediate post-harvest period usually involves many costs. In Nigeria, these costs are so high that lowering the costs through efficient distributive/marketing system may be as important as increasing agricultural production (Ahmed and Rustagi, 1987; Adejobi and Adeyemo, 2012).

Therefore, the issue of how much food gets to the households, which is fundamental in household's food security, is a function of food production level, food marketing/distribution efficiency and the households' income level (Ladele and Ayoola, 1997). Idachaba (2004), observed that food distribution/marketing problems are evidenced when farmers, who are the primary producers residing mostly in rural areas could not get their produce to the market at the right time as a result of inefficient distributive/ market system which leads to considerable post-harvest losses and which reduces the returns for their efforts. The wastages have been on the increase despite the measure put in place to check them. The performance of various categories of intermediaries involved in channel management of agricultural output have not been satisfactorily assessed to establish their operational efficiency, particularly the extent to which they account for these losses as they undertake their distributive trade functions (Christiansen et al, 2003).

It is uncertain, if all categories of intermediaries differ in their marketing efficiency as well as their gross margins from operations. Understanding various categories of distributive channels and the relative efficiencies of the various channels in the marketing of onions will provide solutions to the problems encountered in making onions available to the final consumers. From the foregoing explanations, the study described the socio-economic characteristics of the identified channel operators in the study area, estimated the marketing efficiencies of the identified channel operators and determined the factors that affect marketing efficiencies.

\section{CONCEPTUAL FRAMEWORK}

In Nigeria, commercial onion production is mainly in the North. Sokoto and Kebbi states are among the states in the north where considerable quantity of onion is produced annually (Ayodele 1996). This study adopted the concept (Fig 1) of Dogondaji., Baba, and Mohammed (2006) distributive trade channel. There are intermediaries in the distributive business which include bulk merchant, wholesalers and retailers based on the quantity of onion been handled. Retailers display their onion in small heaps on the ground while wholesalers usually buy directly from either farmers or the bulk merchants who gathered onions through the aid of 
bulk agents that transport sizeable quantities for sale in other states. Most onion producers/farmers sell their produce either to the bulk merchants or at the urban market. Further observations shows that wholesalers receive their supplies from two main sources: farmers, who transport directly to the markets and bulk merchants who buy at the farm gate, homes or rural markets and transport to the urban markets. Retailers source their supplies from wholesalers operating in urban market or directly from the farmers. Finally, retailers sell in small quantities to consumers.

\section{MATERIAL AND METHODS}

Major towns in the state (study area) are characterized with markets for onions and other commodity especially the food crops. The strong and interlinked road network within the state facilitates the distribution of food crops in the state. The study employed the collection of primary data and multi-stage sampling technique in selecting the respondents. The first stage involved the purposive selection of six towns/cities in the state. The second stage involved the random selection of two markets from each of the selected cities to have twelve markets. Stratifications of onion marketers in each market into bulk merchants, wholesalers and retailers for better identification of channel operators is the third stage. The final stage involved the selection of three respondents each from the bulk merchants' stratum and wholesalers' stratum and four respondents from the retailers' stratum per market through a simple random sampling, making ten marketers per market. Overall, one hundred and twenty marketers were interview.

\subsection{Specifications of the Models}

Descriptive statistics, marketing efficiency analytical tools and regression model are the analytical tool used for this study.

\subsubsection{Marketing Efficiency}

Marketing efficiency of the channel operators is a function of both pricing and operational efficiency. Marketing efficiency is:

\section{value added by marketing activities} marketing costs

In other words,

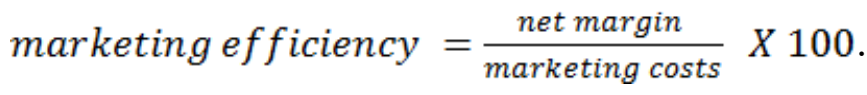

Since,

net margin $=$ marketing margin - marketing Cost

Therefore,

marketing efficiency $=\frac{\text { marketing margin }- \text { marketing cost }}{\text { marketing costs }} \times 100 \ldots$ (3) 


\subsubsection{Regression Models}

Multiple regression models: double log, semi-log, linear and exponential were use to estimate the factors that influence the marketing efficiencies of the operators and the lead model is the linear regression model

Implicitly, the model adopted is:

$\mathrm{Y}=\mathrm{f}(\mathrm{X} 1, \mathrm{X} 2, \mathrm{X} 3, \mathrm{X} 4, \mathrm{X} 5, \mathrm{X} 6 \mathrm{X} 7, \mathrm{X} 8$, ei)

The explicit function:

$\mathrm{Yi}=\mathrm{a} 0$ + á1X1 + á2X2 + á3X3+á4X4 +á5X5+á6X6+á7X7+á8X6+á9X7 +á10X8+Ui

Where,

$\mathrm{Y}=$ Marketing efficiency $(\%)$.

$\mathrm{X} 1=$ Sales volume $(\mathrm{Kg}) . \mathrm{X} 2=$ Losses incurred in transaction $(\mathrm{Kg}) . \mathrm{X} 3=$ Cost of capital used (interest on loans and depreciation charges on fixed assets). X4 = wages $(\mathrm{N}) . \mathrm{X} 5=$ Transportation costs ( $\mathrm{N}) . \mathrm{X} 6=$ Association dues ( $)$. X7 $=$ Stall rent ( $)$. X8 $=$ Types of channel member, Dummy, 1, $2 \& 3$ (with $1=1$ if retailer, 0 , otherwise; $2=1$ if wholesaler, 0 , otherwise; $3=1$ if bulk merchants, 0 , otherwise).

\section{RESULTS AND DISCUSSION}

\subsection{Socio-Economic Characteristics of Onion Marketers}

There are some social economic characteristics of the onion marketers, which by nature and processes are likely to affect the marketing efficiency and the overall performance of the business.

\subsubsection{Age of Respondents}

Age is an important factor that affects marketing efficiency of marketers. Table 1, showed that a larger percentage (75\%) of onion bulk merchants are between 20-29 years of age while no respondents in the wholesalers and retailers strata fall within this age range. There is pooled mean age of 40 and standard deviation of 9.69. It means that onions bulk merchants are youth. This may probably be owing to the fact that majority of the bulk merchants are from the northern part of the country, a region characterized with high incidence of nonschooling (US Embassy, 2012). This contributes to the early age involvement of people from the region into other means of livelihood rather than schooling, which is contrary to what is obtainable in southwestern part of the country where the wholesalers and retailers reside.

\subsubsection{Gender of Respondents}

Since marketing of some products is gender sensitive. Thus, gender plays an important role in marketing efficiency of marketers or markets operators. Onion bulk merchants are predominantly $(77.8 \%)$ male while onion wholesaling and retailing are in the hands of female marketers (Table, 2). Apart from the energy-demanding task involved in transporting onion from the northern to the southern part of the country, the religion and socio-cultural values of the northerners prevents women/female folks from being bulk merchants. 


\subsubsection{Years Completed in Formal School}

Table 3, revealed that $38.9 \%$ of onion bulk merchants had zero year completed in formal schooling which means they are not lettered compared to what is obtainable in the wholesalers and retailers' stratum where there is no operators without having formal education. The result furthered showed a pooled mean value of 6.90 and standard deviation of 3.6 .

Low level of education can be traced to the fact that the northern region where the bulk merchants come from have between $60-65 \%$ of primary school age children that never attended school compare to less than 3\% in the southern state (US Embassy, 2012). Possibility of this affecting the marketing efficiency of the bulk merchants is high, since direct relationship between marketing efficiency and level of literacy should exist.

\subsubsection{Marital Status}

The study discovered that, $63.9 \%$ of onion bulk merchants were married and majority of the wholesalers and retailers $(83.3 \%$ and $62.5 \%$ respectively) were married with no respondents being single. The result of the pooled data on marital status distribution indicated that $84.2 \%$ of onion marketers were married (Table 4). Since each stratum as well as all strata has a preponderance of married marketers, enhance marketing efficiency is expected (Uguwumba, 2009; Jimoh, 2014).

\subsubsection{Credit Access}

Credit access is pivotal to business expansion in most developing countries. The study further observed that not all the Bulk Merchants and majority of wholesalers (91.7\%) and retailers $(97.9 \%)$ had access to credit facilities (Table 5). It indicated that onion marketing did not attract funding from formal or informal sources or that the marketers do have necessary information as regards credit availability. This is a potential hindrance to business expansion for the onion market intermediaries.

\subsubsection{Experience in Business}

The bulk merchants interviewed during the research work had less years of experience in the business compared to other strata (Table 6). This might be because of the age factor, the bulk merchants leave the business for the young ones, because of their inability to cope with the herculean tasks associated with conveyance of onions from the northern region to the study area.

\subsection{Marketing Efficiency}

Marketing efficiency of the channel operators is a function of both the pricing and operational efficiency. Table 7, 8 and 9 shows that highest net marketing margin in naira per $120 \mathrm{~kg}$ of onion for bulk merchants and wholesalers were highest in Osogbo at 1,496.4 and $\$ 387$, respectively while the net marketing margin in naira per $30 \mathrm{~kg}$ of onions for retailers was highest in Osogbo at $\$ 220$. The lowest net marketing margin was found in Iwo for the bulk merchants (899.0) and Ikirun has the lowest net marketing margin for the wholesalers and retailers strata ( 283.0 and 130.0 respectively). The average marketing costs of onions in the study area were $1,030.01, \$ 12.8$ and $\$ 66.7$ for the bulk merchants, wholesalers and retailers respectively. 
The marketing efficiency was highest in Osogbo for all the channel operators $(149 \%, 343 \%$, and $275 \%$ for bulk merchants, wholesalers and retailers respectively). The very high marketing efficiency means an efficient marketing system; however, according to Olukosi and Isitor (1990), market efficiency is a function of both pricing and operational efficiencies. Babatunde and Oyatoye (2008) established this in a work where the average marketing efficiency of maize enterprise per $100 \mathrm{~kg}$ in the study area was $143.5 \%$ and interpreted to mean an efficient marketing system. Channel operators in the study area could therefore interpret the result in this study to mean a high pricing efficiency in onion marketing.

\subsection{Regression Analysis}

A number of factors usually affect marketing efficiency. Based on the significance of their parameters estimate, the factors identified to be affecting marketing efficiency of onions marketers in Osun State are losses incurred in transaction, sales volume, transportation and storage costs and cost of capital used. The lead equation is the linear equation

$$
\text { : } Y=b \_0+b \_1 X \_1+b \_2 X \_2+b \_3 X \_3+b \_4 \text { X_4+b_5 X_5+b_6 X_6 }
$$

Table 11 shows that coefficient of all the independent variables [i.e. losses incurred in transaction, sales volume, transportation cost, wastages, association dues, stall rents and cost of capital used had significant effect on the marketing efficiency. Hence, they all have the tendency to predict the marketing efficiency. The variables included in the model had the coefficients significant between $1 \%(\mathrm{p}<0.01)$ and $10 \%(\mathrm{P}<0.1)$. The adjusted $\mathrm{R} 2$ was 0.75 , which suggests that a good deal $(75 \%)$ explanations of the variations in the marketing efficiency of marketers by the independent variables. More explicitly:

Sales Volume: this is positively related to the marketing efficiency and significant. It inferred that a percentage increase in sales volume would increase the marketing efficiency by $1134 \%$. This implies that onion marketers that sell in larger volumes are more efficient than those that sell otherwise.

Loss Incurred in transaction: significant and positively related to the dependent variable, which contradicts a priori expectation. This means that one percent increase in the loss incurred in transaction will increase the marketing efficiency by $278 \%$. Low level of wastages and the preservative measures used by the marketers are responsible for this contradiction.

Cost of capital used: any 10\% increase in the cost of capital used would decrease the marketing efficiency by $1681 \%$. It explained that the more the marketers pay interest on loan and incurred more depreciation charges on fixed asset the lower the marketing efficiency and vice versa.

Wages: this variable was also significant and inversely related to the marketing efficiency. This implies that as the wages increase by one percent, the marketing efficiency decreases by $731 \%$ and vice versa. The implication of this is that the more the cost incurred in terms of wages, the less efficient the marketing will be.

Transportation Cost: the variable shows that as the transportation cost increases the marketing efficiency decreases and vice versa. This implies that the more the cost incurred on transportation, the less efficient the market will be and that one percent increase in the transportation cost will decrease the marketing efficiency by $1,235 \%$. The bulk merchants 
that had to transport the onions from the northern region of the country (source of production) to the study area incurred more cost, which reflected on their high marketing costs.

Association Dues: is significant and positively related to the dependent variable.

Stall rent: significant and positively related to the dependent variable contrary to what is expected. This implies that $5 \%$ increase in stall rents will increase the marketing efficiency by $201 \%$. It is a fact that most of the marketers sell in the open space that serves as an alternative and helps them to avoid renting a stall. This reduces the additional cost that marketers should have incurred.

\section{CONCLUSIONS}

From the study, there are significant differences in the ages of the identified channel operators in the study area. In addition, there are significant differences in the education levels of identified channel operators. There were no significant differences between the years of experience of the identified channel operators in the study area. The factors that influenced the marketing efficiency of onion marketers were; losses incurred in transaction, sales volume, transportation cost, wages, association dues, stall rent and cost of capital used. Larger percentages of the onion marketers do not have access to credit facilities with price fluctuation been experienced during Ramadan period.

\section{REFERENCES}

ADEJOBİ, A.O. (2005). Cowpea Marketing in Maiduguri, Borno State. Monograph No. 1; DFID/the Nigerian Marketing Network Policy Brief. (pp 31).www.dur.ac.uk/nigerian.marketing.

ADEJOBİ, A.O. \& ADEYEMO, V.A.(2012). The nature and determinants of channel levels in cassava and cassava product markets in southwest Nigeria. Journal of International Food and Agribusiness Marketing. Vol24. Issue 4 pg. 273-287

Agricultural Information (2011). Importance of vegetables; publication from my agriculture information bank site. Retrieved from www.agriciinfo.net

Agricultura 1Technology Portal. (2008). Agricultural marketing and Agri-business Journal, TNAU Agrictech portal, TamilNadu Agriculture University, Coimbatore

AHMED, R. \& RUSTAGİ, N. (1987). Marketing and Price Incentives in African and Asian

Countries in Elz, D. (ed), Agricultural Marketing Strategy and pricing Policy, International

Bank for Reconstruction and Development. Washington, USA.

AYINDE, I.A. (2005). Market dynamics for cowpeas: Weight and Measurement issues in Kuto Market, Abeokuta, Nigeria. DFID/The Nigerian Marketing Network Policy Brief. Retrieved from www.dur.ac.uk/nigerian.marketing

AYODELE, V.I. (1996). Onion production in Ibadan, Southwest, Nigeria: Prospects and Limitation. Paper presented at the 11th annual conference of the Horticultural Society of Nigeria. 
BABATUNDE, R.O. \& OYATOYE, E. (2008). Food Security and Marketing Problems in Nigeria. The case of maize marketing in Kwara State. Research Journal of Agriculture and Biological Sciences, Vol. 4 (5): 443-452.

CHRİSTIANSEN.O., COURSEY, D.G., \& R.H. BOOTH (2003). Root and Tuber Crops. In leaky, C.E.A and J.H Wills (Eds). Food-Crops of the lowland Tropics, Oxford University Press.

DOGONDAJI, S.D., BABA, K.M \& MOHAMMED, I. (2006). Marketing Analysis of Onion in Sokoto and Kebbi States of Nigeria, Savannah Journal of Agriculture. Volume 1 Number 2 December 2006.

HUSSANI, M. A., AMANS, E.B., \& RAMALAN, A.A (2000). Yield, bulb size distribution and storability of onion (Allium cepa. L.) under different levels of $\mathrm{N}$ fertilization and irrigation regime. Tropical Agriculture (Trinidad).77(3): 145-149.

IDACHABA, F.S. (2004). Food Security in Nigeria: challenges Under Democratic Dispensation, 9th ARMTI Annual Lecture, Ilorin, 24/3/2004.

JIMOH, I. S. (2014). Economic Analysis of Plam Oil Marketing in Dekina Local Government area of Kogi State, Nigeria: Asian Journal of Social Science, Arts and Humanities, Vol 2. No 1, 2014

LADELE, A. A. \& AYOOLA, G.B. (1997). Food Marketing and it's Role in Food Security in Nigeria: inShaib, B. ;Adedipe, N.O. ; Aliyu, A and Jir, M.M. (eds); Intergrated Agricultural Production in Nigeria; Strategies and Mechanisms for Food Security. Proceeding of the National Workshop on Nigeria Position at the World Food Summit, Abuja, Nigeria. pp 88

UGUWUMBA, C.O.A (2009). Analysis of Fresh Maize Marketing in Anambra State, Nigeria; Journal of Research in Natural Development Vol 7 No 2, December 2009

US Embassy, (2012). Nigeria Education Fact Sheet; Economic Section, United State Embassy in Nigeria. http://nigeriausembassy.gov. 


\section{TABLES}

Table 1. Distribution of Respondents by Age

\begin{tabular}{|c|c|c|c|c|c|c|c|}
\hline \multirow{3}{*}{$\frac{\bar{\Xi}}{\square}$} & 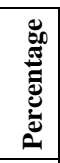 & $\begin{array}{l}n \\
\tilde{i}\end{array}$ & $\begin{array}{l}n \\
\stackrel{n}{\sim}\end{array}$ & $\hat{m}$ & $\stackrel{m}{m}$ & in & 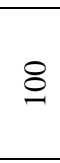 \\
\hline & 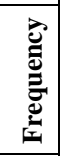 & $\bar{\lambda}$ & ले & $\stackrel{\infty}{m}$ & $\stackrel{\circ}{0}$ & 0 & 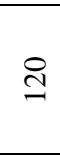 \\
\hline & $\stackrel{8}{<}$ & $\begin{array}{l}\text { ते } \\
\text { ஸे }\end{array}$ & $\begin{array}{c}\text { के } \\
\text { हे }\end{array}$ & $\begin{array}{l}\stackrel{q}{+} \\
\stackrel{+}{q}\end{array}$ & $\begin{array}{l}\text { nे } \\
\text { in }\end{array}$ & $\begin{array}{l}8 \\
\end{array}$ & 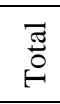 \\
\hline \multirow{3}{*}{ 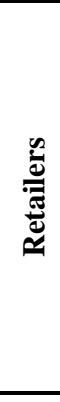 } & 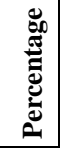 & 0 & $\stackrel{\vec{c}}{w}$ & के & चे & 0 & $\stackrel{\varrho}{1}$ \\
\hline & 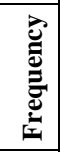 & 0 & I & 2 & $\simeq$ & 0 & $\stackrel{\infty}{\stackrel{\circ}{\prime}}$ \\
\hline & $\stackrel{8}{*}$ & $\begin{array}{l}\text { iे } \\
\text { ஸे }\end{array}$ & के & $\begin{array}{l}\text { aे } \\
\text { o }\end{array}$ & $\begin{array}{l}\text { n̂े } \\
\text { in }\end{array}$ & $\begin{array}{l}8 \\
\Lambda_{1}\end{array}$ & $\stackrel{\bar{\Xi}}{0}$ \\
\hline \multirow{3}{*}{ 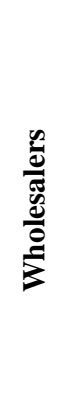 } & 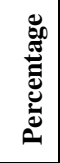 & 0 & ले & $\begin{array}{l}n \\
f^{\prime}\end{array}$ & $\stackrel{\overbrace{}}{=}$ & $=$ & 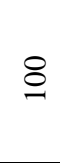 \\
\hline & 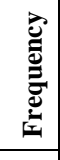 & 0 & $\simeq$ & $\stackrel{0}{0}$ & $\nabla$ & $\checkmark$ & ల \\
\hline & $\stackrel{8}{4}$ & $\begin{array}{l}\text { ते } \\
\text { ते }\end{array}$ & के & $\begin{array}{l}\stackrel{q}{+} \\
\stackrel{+}{q}\end{array}$ & $\begin{array}{l}\text { ڤे } \\
\text { in }\end{array}$ & $\begin{array}{l}\overbrace{0} \\
11\end{array}$ & 隐 \\
\hline \multirow{3}{*}{ 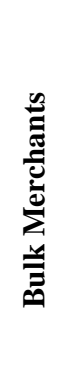 } & 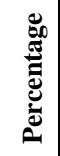 & $\stackrel{n}{2}$ & $\exists$ & $m_{\infty}^{m}$ & 0 & $\begin{array}{l}0 \\
\text { in }\end{array}$ & 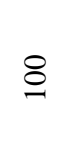 \\
\hline & 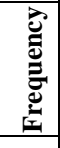 & $\hat{\imath}$ & $\nabla$ & $m$ & 0 & $N$ & ల \\
\hline & $\stackrel{8}{4}$ & $\begin{array}{l}\text { ते } \\
\text { ஸे }\end{array}$ & के & $\begin{array}{l}\stackrel{a}{+} \\
\text { o }\end{array}$ & के & 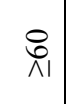 & 丞 \\
\hline
\end{tabular}

Source: Field Survey, 2016 
Table 2. Distribution of Respondents by Sex

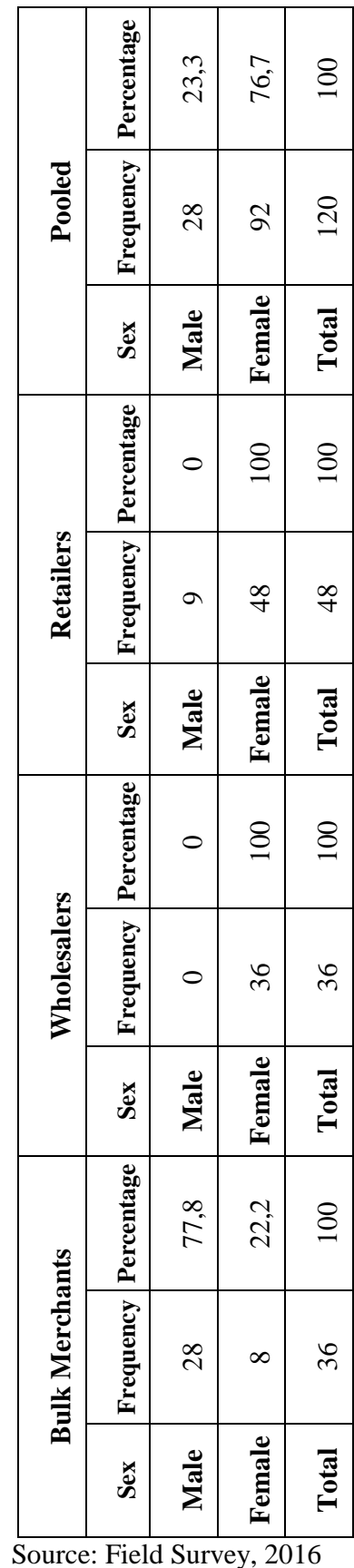


Table 3. Distribution of Respondents by Years completed in Formal School

\begin{tabular}{|c|c|c|c|c|c|}
\hline \multirow{3}{*}{$\begin{array}{l}\frac{\pi}{0} \\
\frac{0}{8} \\
\stackrel{0}{0}\end{array}$} & 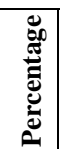 & $\approx$ & $\sqrt{6}$ & $\begin{array}{l}0 \\
\dot{\theta} \\
\dot{\sim}\end{array}$ & 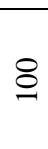 \\
\hline & 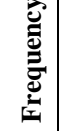 & \pm & $\underset{N}{ \pm}$ & กี & $\stackrel{\text { 工 }}{ }$ \\
\hline & 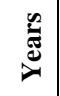 & 0 & $\stackrel{0}{I}$ & $\frac{1}{r}$ & है \\
\hline \multirow{3}{*}{ 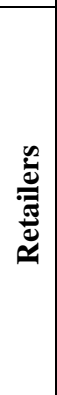 } & 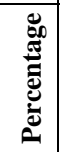 & 0 & 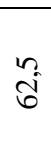 & $\frac{n}{n}$ & § \\
\hline & 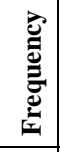 & 0 & હે & $\infty$ & $\stackrel{\infty}{+}$ \\
\hline & 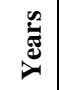 & 0 & $\frac{0}{1}$ & $\frac{T}{r}$ & $\stackrel{\bar{T}}{0}$ \\
\hline \multirow{3}{*}{ 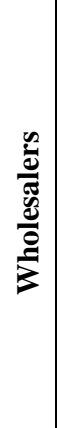 } & 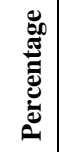 & 0 & $\stackrel{\infty}{\stackrel{\infty}{N}}$ & & $\stackrel{8}{\varrho}$ \\
\hline & 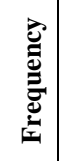 & 0 & $\stackrel{\infty}{\sim}$ & $\infty$ & r \\
\hline & 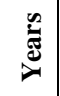 & 0 & $\frac{0}{I}$ & $\frac{1}{1}$ & 疍 \\
\hline \multirow{3}{*}{ 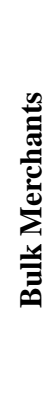 } & 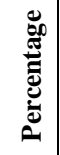 & $\hat{\infty}$ & $\stackrel{+}{\underset{f}{f}}$ & $\hat{\theta}$ & ○ \\
\hline & 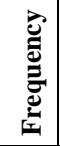 & \pm & $\underline{0}$ & 0 & లి \\
\hline & 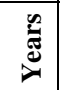 & $\theta$ & $\stackrel{0}{I}$ & $\frac{1}{2}$ & हే \\
\hline
\end{tabular}

Source: Field Survey, 2016 
Table 4. Distribution of Respondents by Marital Status

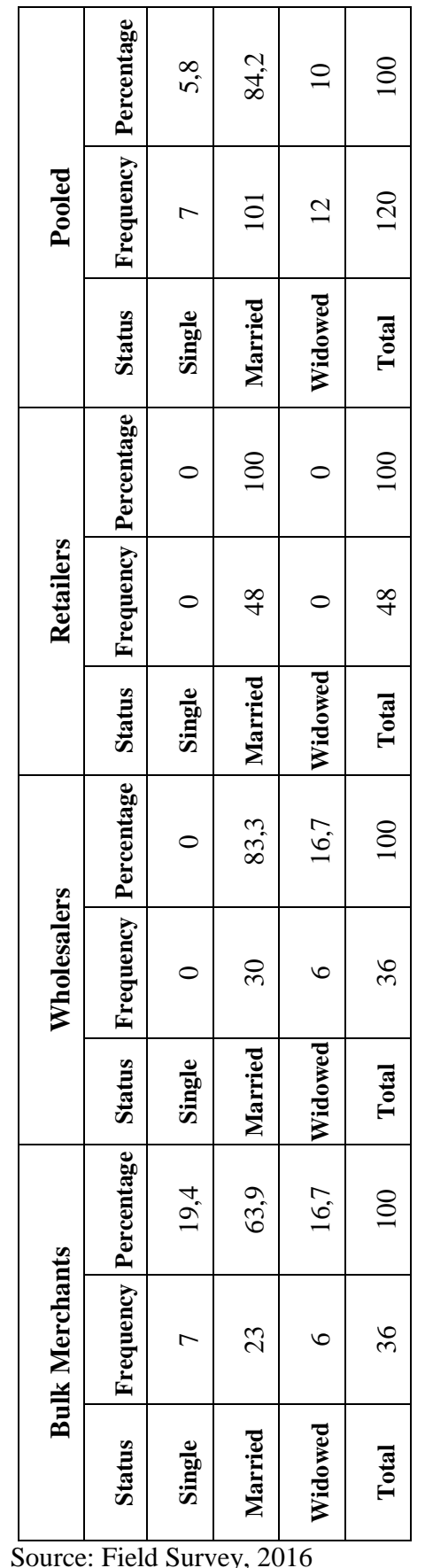

Source: Field Survey, 2016 
Table 5. Distribution of Respondent by Access to Credit

\begin{tabular}{|c|c|c|c|c|}
\hline \multirow{3}{*}{ 冚 } & 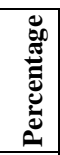 & $\stackrel{m}{m}$ & $\hat{\delta}$ & 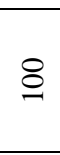 \\
\hline & 竧 & $\nabla$ & $\stackrel{\varrho}{=}$ & 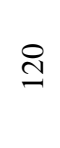 \\
\hline & 昰 & 总 & 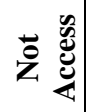 & స్ \\
\hline \multirow{3}{*}{ 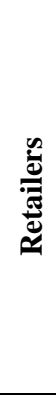 } & 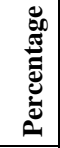 & $\vec{i}$ & ลे & 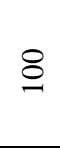 \\
\hline & 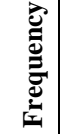 & - & F & $\stackrel{\infty}{+}$ \\
\hline & 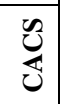 & 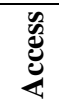 & 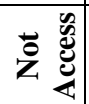 & हूँ \\
\hline \multirow{3}{*}{ 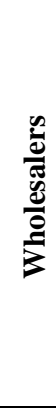 } & 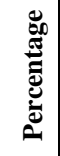 & $\stackrel{m}{\infty}^{m}$ & $\tilde{a}$ & 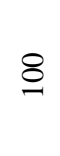 \\
\hline & 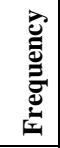 & $m$ & $m$ & ల్ల \\
\hline & $\begin{array}{l}0 \\
0 \\
0 \\
0 \\
\end{array}$ & $\begin{array}{l}\frac{n}{8} \\
\frac{8}{4}\end{array}$ & 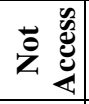 & हूँ \\
\hline \multirow{3}{*}{ 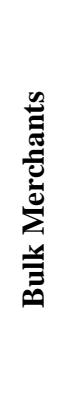 } & 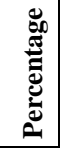 & 0 & 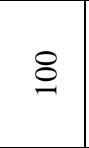 & 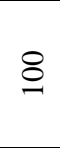 \\
\hline & 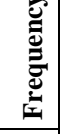 & 0 & ల్ల & లr \\
\hline & 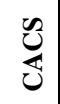 & 离 & 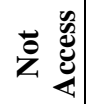 & 嵒 \\
\hline
\end{tabular}


Table 6. Distribution of Respondents by Years of Experience in the Business

\begin{tabular}{|c|c|c|c|c|c|c|c|c|c|}
\hline \multirow{3}{*}{ : } & 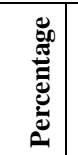 & å & $\stackrel{m}{\infty}$ & $\begin{array}{l}n \\
\tilde{N}\end{array}$ & 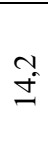 & $\stackrel{\infty}{0}$ & $\stackrel{m}{m}$ & $\cong$ & 8 \\
\hline & 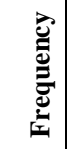 & $=$ & $\stackrel{\infty}{n}$ & $\hat{\sim}$ & I & - & $\nabla$ & $N$ & 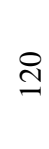 \\
\hline & 武 & in & 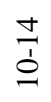 & $\frac{a}{n}$ & 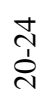 & $\begin{array}{l}\text { ते } \\
\text { ஸे }\end{array}$ & 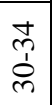 & $\tilde{\hat{\Lambda}}$ & 苞 \\
\hline \multirow{3}{*}{ 党 } & 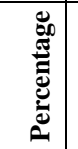 & 0 & $\vec{n}$ & 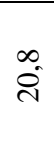 & $\vec{\sim}$ & 0 & 0 & 0 & 8 \\
\hline & 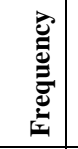 & 0 & $\stackrel{\sim}{\sim}$ & $\stackrel{0}{ }$ & 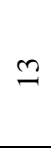 & 0 & 0 & 0 & $\stackrel{\infty}{+}$ \\
\hline & 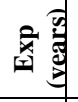 & in & $\frac{ \pm}{0}$ & $\frac{a}{n}$ & 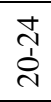 & $\begin{array}{l}\text { ते } \\
\stackrel{\sim}{1}\end{array}$ & 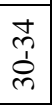 & $\tilde{\hat{\wedge}}$ & 苞 \\
\hline \multirow{3}{*}{ 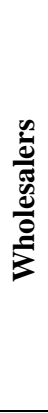 } & 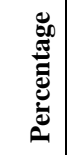 & $\stackrel{a}{\ddot{g}}$ & $\begin{array}{l}\infty \\
\text { in }\end{array}$ & $m_{\infty}^{\infty}$ & $\exists$ & $\stackrel{\infty}{\sim}$ & $\exists$ & 0 & 8 \\
\hline & 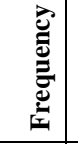 & $n$ & 9 & $m$ & $\nabla$ & - & $\nabla$ & 0 & r \\
\hline & 周 & $\hat{a}$ & $\frac{ \pm}{d}$ & $\frac{a}{n}$ & 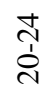 & $\begin{array}{l}\text { సे } \\
\stackrel{\sim}{\sim}\end{array}$ & 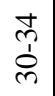 & $\tilde{\wedge}$ & 䒿 \\
\hline \multirow{3}{*}{ 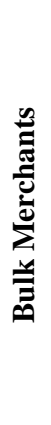 } & 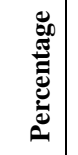 & $\overbrace{0}^{n}$ & ले & $\begin{array}{l}\hat{\infty} \\
\infty^{\circ}\end{array}$ & 0 & 0 & 0 & $\begin{array}{l}0 \\
i n\end{array}$ & 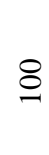 \\
\hline & 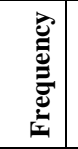 & 0 & \pm & \pm & 0 & 0 & 0 & $N$ & ల) \\
\hline & 居氞 & à & $\frac{ \pm}{d}$ & $\frac{a}{n}$ & 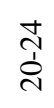 & $\begin{array}{l}\text { సे } \\
\stackrel{2}{\sim}\end{array}$ & के & $\ddot{\wedge}$ & స్ㅠㅇ \\
\hline
\end{tabular}

Source: Field Survey, 2016 
ALANYA AKADEMİK BAKIŞ DERGİSİ 2/2 (2018)

Table 7. Marketing Efficiency of Onions Bulk merchants in the Study area

\begin{tabular}{|c|c|c|c|c|c|c|}
\hline Cities & $\begin{array}{r}\text { Cost } \\
\text { Price } \\
/ 120 \mathrm{~kg} \\
\end{array}$ & $\begin{array}{r}\text { Selling } \\
\text { Price } \\
/ 120 \mathrm{~kg} \\
\end{array}$ & $\begin{array}{r}\text { Market } \\
\text { Cost } \\
/ 120 \mathrm{~kg} \\
\end{array}$ & $\begin{array}{c}\text { Market } \\
\text { Margin } \\
/ 120 \mathrm{~kg}\end{array}$ & $\begin{array}{r}\text { Net } \\
\text { Margin } \\
/ 120 \mathrm{~kg} \\
\end{array}$ & $\begin{array}{r}\text { Market } \\
\text { efficiency } \\
\%\end{array}$ \\
\hline Osogbo & 6000 & 8500 & 1003.6 & 2500 & 1496.4 & 149 \\
\hline Ede & 6000 & 8200 & 1001.2 & 2200 & 1198.8 & 120 \\
\hline Ife & 6500 & 8500 & 1007 & 2000 & 993 & 99 \\
\hline Iwo & 6400 & 8500 & 1101.3 & 2000 & 899 & 82 \\
\hline Ilesa & 6000 & 8500 & 1044.2 & 2500 & 1455.8 & 139 \\
\hline Ikirun & 6000 & 8000 & 1022.8 & 2000 & 977 & 96 \\
\hline Average & 6750 & 8950 & 1030.01 & 2200 & 1168.3 & 114.2 \\
\hline
\end{tabular}

Source: Field Survey, 2016

Table 8. Marketing Efficiency of Onions Wholesalers in the Study area

\begin{tabular}{lrrrrrr}
\hline Cities & $\begin{array}{r}\text { Cost } \\
\text { Price } \\
\text { /120kg }\end{array}$ & $\begin{array}{r}\text { Selling } \\
\text { Price } \\
\text { /120kg }\end{array}$ & $\begin{array}{r}\text { Market } \\
\text { Cost } \\
\mathbf{1 2 0 k g}\end{array}$ & $\begin{array}{r}\text { Market } \\
\text { Margin } \\
\text { /120kg }\end{array}$ & $\begin{array}{r}\text { Net } \\
\text { Margin } \\
\text { /120kg }\end{array}$ & $\begin{array}{r}\text { Market } \\
\text { efficiency }\end{array}$ \\
\hline & & & & & & $\mathbf{\%}$ \\
Osogbo & 8500 & 9000 & 113 & 500 & 387 & 343 \\
Ede & 8200 & 8600 & 105 & 400 & 295 & 281 \\
Ife & 8500 & 8950 & 110 & 450 & 340 & 291 \\
Iwo & 8500 & 8900 & 117 & 400 & 283 & 242 \\
Ilesa & 8500 & 9000 & 115 & 500 & 385 & 335 \\
Ikirun & 8000 & 8400 & 117 & 400 & 283 & 241 \\
Average & $\mathbf{8 9 5 0}$ & $\mathbf{9 3 9 2}$ & $\mathbf{1 1 2 . 8}$ & $\mathbf{4 4 2}$ & $\mathbf{3 2 8 . 8}$ & $\mathbf{2 8 8 . 8}$ \\
\hline
\end{tabular}

Source: Field Survey, 2016 
Table 9. Marketing Efficiency of Onions Retailers in the Study area

\begin{tabular}{lrrrrrr}
\hline Cities & $\begin{array}{r}\text { Cost } \\
\text { Price }\end{array}$ & $\begin{array}{r}\text { Selling } \\
\text { Price }\end{array}$ & $\begin{array}{r}\text { Market } \\
\text { Cost }\end{array}$ & $\begin{array}{r}\text { Market } \\
\text { Margin }\end{array}$ & $\begin{array}{r}\text { Net } \\
\text { Margin }\end{array}$ & $\begin{array}{r}\text { Market } \\
\text { efficiency }\end{array}$ \\
& $\mathbf{3 0 k g}$ & $\mathbf{3 0 k g}$ & $\mathbf{3 0 k g}$ & $\mathbf{3 0 k g}$ & & \% \\
\hline & & & & & & \\
Osogbo & 2200 & 2500 & 80 & 300 & 220 & 275 \\
Ede & 2100 & 2300 & 60 & 200 & 140 & 233 \\
Ife & 2200 & 2430 & 65 & 230 & 165 & 253 \\
Iwo & 2200 & 2400 & 65 & 200 & 135 & 208 \\
Ilesa & 2200 & 2450 & 70 & 250 & 180 & 257 \\
Ikirun & 1950 & 2140 & 60 & 190 & 130 & 217 \\
Average & $\mathbf{2 2 9 2}$ & $\mathbf{2 5 2 0}$ & $\mathbf{6 6 . 7}$ & $\mathbf{2 2 8 . 3}$ & $\mathbf{1 6 1 . 7}$ & $\mathbf{2 4 0 . 5}$ \\
\hline
\end{tabular}

Source: Field Survey, 2016

Table 10. Factors Affecting marketing Efficiency of Onion Marketers (Pooled Data)

\begin{tabular}{lll} 
Variable & Coefficient & p-value \\
\hline Constant & 6.3708 & 0.000 \\
Sales volume $\left(\mathrm{X}_{1}\right)$ & 11.337 & $0.000^{*}$ \\
Losses incurred in transaction $\left(\mathrm{X}_{2}\right)$ & 2.786 & $0.006^{*}$ \\
Cost of capital used $\left(\mathrm{X}_{3}\right)$ & -1.681 & $0.096^{* * *}$ \\
Wages $\left(\mathrm{X}_{4}\right)$ & -7.306 & $0.000^{*}$ \\
Transportation cost $\left(\mathrm{X}_{5}\right)$ & -12.345 & $0.000^{*}$ \\
Association dues $\left(\mathrm{X}_{6}\right)$ & 3.145 & $0.002^{*}$ \\
Stall rent $\left(\mathrm{X}_{7}\right)$ & 2.012 & $0.047^{* *}$
\end{tabular}

Source: Field Survey, 2016 


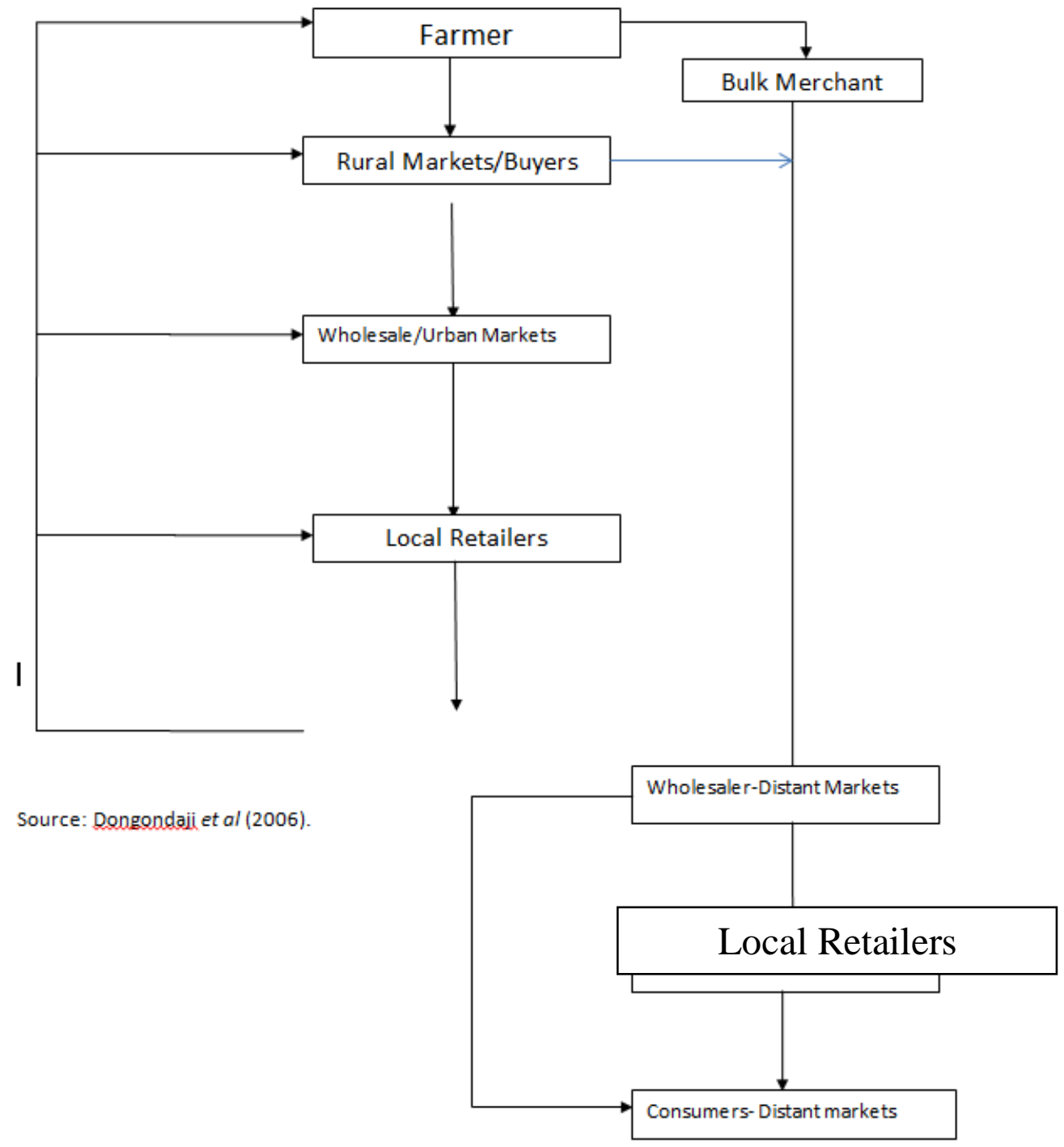

Fig 1: A Typical Distributive Trade Channel for Onions 


\section{Footnotes}

CACS $=$ Credit Access

$\operatorname{Exp}(\mathrm{yrs})=$ Experience in years

* means significant at $1 \%$

** means significant at 5\%

***means significant at $10 \%$

Adjusted $R^{2}=0.75$ 